\title{
Chemical constiuents from Richardia grandiflora (Cham. \& Schltdl.) Steud. (Rubiaceae)
}

\author{
Anna Cláudia de A. Tomaz, * Raquel Bezerra S. S. Nogueira, Danielle Serafim Pinto, Maria \\ de Fátima Agra, Maria de Fátima V. de Souza, Emídio V. Leitão da-Cunha
}

Laboratório de Tecnologia Farmacêutica, Universidade Federal da Paraíba, Caixa Postal 5009, $58051-970$

João Pessoa-PB, Brazil

\begin{abstract}
RESUMO: "Constituintes químicos de Richardia grandiflora (Cham. \& Schltdl.) Steud. (Rubiaceae)". Dentre as diversas formas de terapia para a prevenção e cura de doenças, as plantas foram, indubitavelmente, as mais amplamente utilizadas desde o início da humanidade. O Brasil tem grande diversidade de plantas com potenciais medicinais, ainda não pesquisados, e que são promissoras fontes de inovações terapêuticas e farmacológicas. A família Rubiaceae, considerada a maior da ordem Gentianales, possui cerca de 637 gêneros e 10.700 espécies. Richardia grandiflora (Cham. \& Schltdl.) Steud., conhecida popularmente como ervanço, poaia ou ipeca-mirim, tem indicações etnofarmacológicas para uso contra hemorróidas e como vermífugo na forma de decocto. Visando a contribuir com o estudo quimiotaxonômico da família Rubiaceae e tendo em vista a ausência de dados na literatura acerca da constituição química de Richardia grandiflora, esta foi submetida a um estudo fitoquímico para o isolamento de seus constituintes químicos, através dos métodos cromatográficos usuais, e posterior identificação estrutural dos mesmos, utilizando-se os métodos espectroscópicos de $\mathrm{RMN}{ }^{1} \mathrm{H}$ e ${ }^{13} \mathrm{C}$ uni e bidimensionais, além de comparações com modelos da literatura. Deste estudo pioneiro com $R$. grandiflora foram isolados e identificados cinco constituintes: uma mistura dos esteróides $\beta$-sitosterol e estigmasterol, o ácido $o$-hidroxibenzóico, o ácido $m$-metoxi- $p$-hidroxi-benzóico e a feofitina A, todos inéditos no gênero Richardia.
\end{abstract}

Unitermos: Richardia grandiflora, Rubiaceae, $\beta$-sitosterol, estigmasterol, ácido $o$-hidroxibenzóico, ácido $m$-metoxi- $p$-hidroxi-benzóico, feofitina A.

\begin{abstract}
Amongst the different forms of therapy to prevent and cure illnesses, plants have been, undoubtedly, the most utilized ones since the beginning of mankind. Brazil has a great diversity on plants that possess non-researched medicinal potential and are promising sources of therapeutic and pharmacological innovations. The Rubiaceae family is considered the biggest one of the order Gentianales, presenting around 637 genera and 10,700 species. Richardia grandiflora (Cham. \& Schltdl.) Steud., known popularly as "ervanço", "poaia" or "ipeca-mirim", has ethnopharmacological indications to use as decoction against hemorrhoids and as vermifuge. Aiming at contributing to the chemotaxonomic study of the family Rubiaceae and considering the absence of data in literature about the chemical constitution of the species Richardia grandiflora, the latter was submitted to a phytochemical study to isolate its chemical constituents, through usual chromatographic methods, and after identifying them by means of spectroscopic methods such as ${ }^{1} \mathrm{H}$ and ${ }^{13} \mathrm{C}$ NMR, with the add of two-dimensional techniques, besides comparison with literature data. Five constituents were isolated through this first phytochemical study with $R$. grandiflora: a mixture of the steroids $\beta$-sitosterol and stigmasterol, $o$-hydroxy-benzoic acid, $m$-methoxy- $p$-hydroxy-benzoic acid and phaeophitin A, all of them isolated for the first time from the genus Richardia.
\end{abstract}

Keywords: Richardia grandiflora, Rubiaceae, $\beta$-sitosterol, stigmasterol, $o$-hydroxy-benzoic acid, $m$-methoxy-p-hydroxy-benzoic acid, phaeophitin A.

\section{INTRODUCTION}

Amongst the different forms of therapy to prevent and cure illnesses, plants have been, undoubtedly, the most utilized ones since the beginning of mankind. Plants were originally used in their natural form in the preparation of teas, ointments, plasters and others.
Later, especially from the beginning of the XIX century, they served as source for obtaining raw material for the synthesis of drugs. More recently, plants have emerged as keys to the discovery of prototypes that serve as rational basis to the development of medicines (Funari and Ferro, 2005; Albuquerque et al., 2006; Vilegas and Cardoso, 2007) 
Brazil has a great diversity on plants that possess non-researched medicinal potential and are promising sources of therapeutic and pharmacological innovations to the most diverse areas of human health (Almeida et al., 2001; Silva et al., 2003; Rocha et al., 2005; Brandão et al., 2006; Carlini et al., 2006; Silva et al., 2006a;). The medicinal, economical and ecological importance of Brazilian native species, as well as the risk of their extinction by man's predatory action, has been motivating the studies on these plants, seeking their preservation and rational exploitation (Souza et al., 2003; Barbosa-Filho et al., 2005; Falcão et al., 2005; Amaral et al., 2006; Barbosa-Filho et al., 2006a,b,c; Leitão et al., 2006; Lima et al., 2006; Barbosa-Filho et al., 2007; Oliveira et al., 2007; Saúde-Guimarães, et al., 2007; Rocha et al., 2007).

The Rubiaceae family is considered the biggest one of the order Gentianales (Coelho et al., 2006) and presents around 637 genera and 10,700 species (Mongrand et al., 2005). It is composed of plants of varied habit, is cosmopolitan, its species are classified into four subfamilies (Cinchonoideae, Ixoroideae, Antirheoideae e Rubioideae) and 44 tribes, mostly tropical (Robbrecht, 1988).

Rubiaceae has species of great economical importance which are exploited as food, ornamental and in the pharmaceutical industry too (Carvalho et al., 2006). In addition, several species are popularly referred to as toxic and/or medicinal and among these latter there are species of the genus Richardia (Coelho et al., 2006).

Richardia is a genus of about 15 species in the family Rubiaceae, mainly distributed from North to South America. They are annual or more commonly perennial herbs (Lewis and Oliver, 1974).

Species of this genus are reported as weeds (Hauser and Parham, 1969; Monquero, 2003; Monquero and Christoffoleti, 2003; Ronchi et al., 2003; Pedrinho Júnior et al., 2004; San Martin Matheis, 2004; Monquero, 2005; Monquero et al., 2005) and recognize them is important in order to benefit the agricultural planning.

Richardia grandiflora (Cham. \& Schltdl.) Steud. is native to Argentina, Bolivia, Brazil, Paraguay and Uruguay (Lewis and Oliver, 1974). According to Agra et al. (2007), this species is known popularly as "ervanço", "poaia" or "ipeca-mirim", and has ethnopharmacological indications to use as decoction against hemorrhoids and as vermifuge.

There are no data in literature concerning the chemical constitution of the species in question. However, Edeoga et al. (2005) reported the presence of alkaloids, tannins, saponins, steroids, terpenoids, flavonoids and cardiotonic glycosides through preliminary phytochemical screening in Richardia brasiliensis Gomes and reported that it is used in folk medicine to cure eczema, in the treatment of burns and in the active cure to avian malaria. The water and ethanol extracts of this species showed antifungal activity observed by Adekunle (2000).

Therefore, aiming at contributing to the chemotaxonomic study of the family Rubiaceae and considering the absence of data in literature about the chemical constitution of Richardia grandiflora, the latter was submitted to a phytochemical study to isolate and identify its chemical constituents, through usual chromatographic and spectroscopic methods, besides comparison with literature data.

\section{MATERIAL AND METHODS}

\section{Equipments}

NMR spectra $\left({ }^{1} \mathrm{H},{ }^{13} \mathrm{C}\right.$, HMQC, HSQC, HMBC, COSY, NOESY) were run on a Mercury Varian instrument operating at $200 \mathrm{MHz}\left({ }^{1} \mathrm{H}\right)$ and $50 \mathrm{MHz}$ $\left({ }^{13} \mathrm{C}\right)(\mathrm{LTF} / \mathrm{UFPB})$ (substances 1, 2, 4 and 5) and on a BRUKER-AC operating at $500 \mathrm{MHz}\left({ }^{1} \mathrm{H}\right)$ and $125 \mathrm{MHz}$ $\left({ }^{13} \mathrm{C}\right)(\mathrm{CENAUREM})$ (substance 3). The NMR data were measured in $\mathrm{CDCl}_{3}$ and the chemical shifts are expressed in ppm with reference to the solvent signal.

\section{Plant material}

Richardia grandiflora (Cham. \& Schltdl.) Steud. was collected in the city of João Pessoa, State of Paraíba, being identified by Prof. Maria de Fátima Agra from the Botany section of Núcleo de Pesquisa de Produtos Naturais of Laboratório de Tecnologia Farmacêutica (LTF). A voucher specimen is deposited in the Herbarium Professor Lauro Pires Xavier (JPB) from Centro de Ciências Exatas e da Natureza of Universidade Federal da Paraíba (UFPB) under the code M. F. Agra et al. 2953 (JPB).

\section{Extraction, fractionation and isolation of the chemical constituents}

The plant material was subjected to dehydration in an oven in a temperature of $40{ }^{\circ} \mathrm{C}$ for 72 hours; after that, it was grownded in a mechanical mill, yielding 3.164 $\mathrm{kg}$ of a powder which was submitted to maceration with ethanol for three consecutive days. This process was repeated until the maximum extraction of the chemical constituents. The obtained ethanol extractive solution was concentrated in a rotatory evaporator, yielding 400 $\mathrm{g}(12.64 \%$ yield in relation to the dried plant weight) of crude ethanol extract (CEE).

An aliquot of $100 \mathrm{~g}$ of the CEE was subjected to filtration under reduced pressure using silica gel 60 as stationary phase into a funnel of porous plate and was eluted with various systems of solvents (pure or in binary mixtures): Hexane, Hex:AcOEt (9:1), Hex:AcOEt (7:3), Hex:AcOEt (1:1), AcOEt:Hex (6:4), AcOEt:Hex (7:3), AcOEt:Hex (9:1), AcOEt, AcOEt:MeOH (9:1) and 
AcOEt:MeOH (7:3), yielding the respective fractions. The fraction Hex:AcOEt (7:3) (1.238 g) was subjected to column chromatography packed with silica gel 60 and eluted with hexane, ethyl acetate and methanol; 278 fractions of $50 \mathrm{~mL}$ were colected being analysed and joined through analytical thinlayer chromatography (TLC). The sub-fraction 32/76, after being recrystallized in hexane showed itself as crystals, yielding $23 \mathrm{mg}$ of the substance 1 . The subfraction $104 / 149(118 \mathrm{mg})$ was submmited to column chromatography over silica gel 60, giving 137 fractions that were analysed and joined through analytical TLC. The sub-fraction $87 / 120(60 \mathrm{mg})$ showed itself as darkgreen amorphous solid, defined as substance $\mathbf{3}$.

The fraction AcOet:Hex (9:1) (0.569 g) was subjected to column chromatography packed with Sephadex LH 20 and eluted with chloroform and methanol, from which 32 fractions of $15 \mathrm{~mL}$ were colected and then analysed and joined through analytical TLC. The sub-fraction 15/26 (6 mg), after being recrystallized with chloroform showed itself as crystals, yielding the substance 4 .

The fraction Hex:AcOet $(1: 1)(1.895 \mathrm{~g})$ was subjected to chromatography on a column packed with silica gel 60, the eluents were chloroform, ethyl acetate and methanol, giving 128 fractions of $50 \mathrm{~mL}$ that were analysed and joined through analytical TLC. The subfraction 103/104 (182 mg) was submitted to column chromatography packed with silica gel 60 and eluted with hexane, ethyl acetate and methanol, yielding 78 fractions of $50 \mathrm{~mL}$ that were analysed and joined through analytical TLC. The sub-fraction 35/39, after being recrystallized in hexane showed itself as crystals, yielded $4 \mathrm{mg}$ of the substance 5 .

Table 1. ${ }^{1} \mathrm{H}$ and ${ }^{13} \mathrm{C}$ NMR $\left(\delta, \mathrm{CDCl}_{3}, 500\right.$ and $125 \mathrm{MHz}$ ) spectral data 3 (excluding phytyl moiety).

\begin{tabular}{|c|c|c|c|c|c|}
\hline & \multicolumn{2}{|c|}{$\begin{array}{l}{ }^{1} \mathrm{H} \mathrm{x}{ }^{13} \mathrm{C} \\
\mathrm{HSQC}\end{array}$} & \multicolumn{2}{|c|}{$\begin{array}{l}{ }^{1} \mathrm{H} \mathrm{x}{ }^{13} \mathrm{C} \\
\mathrm{HMBC}\end{array}$} & \multirow[t]{2}{*}{$\begin{array}{l}{ }^{1} \mathrm{Hx}{ }^{1} \mathrm{H} \\
\mathrm{COSY}\end{array}$} \\
\hline $\mathrm{C}$ & $\delta_{\mathrm{C}}$ & $\delta_{\mathrm{H}}$ & $J^{2}$ & $J^{3}$ & \\
\hline 1 & 142.34 & & & & \\
\hline 2 & 131.10 & & & & \\
\hline $2^{1}$ & 12.26 & $3.39(\mathrm{~s})$ & C-2 & $\mathrm{C}-1 ; \mathrm{C}-3$ & \\
\hline 3 & 136.82 & & & & \\
\hline $3^{1}$ & 129.19 & $\begin{array}{c}7.95(\mathrm{dd}, J 17,85 \mathrm{~Hz} \\
11.48 \mathrm{~Hz})\end{array}$ & & C-4 & $\mathrm{H}-3^{2}(E ; Z)$ \\
\hline $3^{2}$ & 123.11 & $\begin{array}{c}6.27(E)(\mathrm{d}, J 17.95 \\
\mathrm{Hz}) \text { and } 6.18(Z)(\mathrm{d}, J \\
11.10 \mathrm{~Hz})\end{array}$ & & C-3 & \\
\hline 4 & 136.51 & & & & \\
\hline 5 & 97.66 & $9.35(\mathrm{~s})$ & $\mathrm{C}-4$ & & \\
\hline 6 & 155.55 & & & & \\
\hline 7 & 136.14 & & & & \\
\hline $7^{1}$ & 11.35 & 3,19 (s) & $\mathrm{C}-7$ & C-6; C-8 & \\
\hline 8 & 145.25 & & & & \\
\hline $8^{1}$ & 19.60 & $3.63(\mathrm{~m})$ & $\mathrm{C}-8 ; \mathrm{C}-8^{2}$ & $\mathrm{C}-7$ & $\mathrm{H}-8^{2}$ \\
\hline $8^{2}$ & 17.52 & $1.66(\mathrm{~m})$ & & & \\
\hline 9 & 150.92 & & & & \\
\hline 10 & 104.59 & $9.51(\mathrm{~s})$ & C-11 & & \\
\hline 11 & 138.14 & & & & \\
\hline 12 & 129.03 & & & & \\
\hline $12^{1}$ & 12.32 & $3.69(\mathrm{~s})$ & C-12 & C-11; C-13 & \\
\hline 13 & 129.14 & & & & \\
\hline $13^{1}$ & 189.81 & & & & \\
\hline $13^{2}$ & 64.90 & $6.30(\mathrm{~s})$ & $\begin{array}{c}\mathrm{C}-13^{1} ; \mathrm{C}-13^{3} ; \\
\mathrm{C}-15\end{array}$ & C-14 & \\
\hline $13^{3}$ & 169.77 & & & & \\
\hline $13^{4}(\mathrm{OMe})$ & 53.07 & $3.91(\mathrm{~s})$ & & $C-13^{3}$ & \\
\hline 14 & 149.59 & & & & \\
\hline 15 & 105.10 & & & & \\
\hline 16 & 161.19 & & & & \\
\hline 17 & 51.42 & $4.15(\mathrm{~m})$ & & & \\
\hline $17^{1}$ & 29.89 & & & & \\
\hline $17^{2}$ & 31.42 & & & & \\
\hline $17^{3}$ & 173.18 & & & & \\
\hline 18 & 50.36 & $4.34(\mathrm{~m})$ & & & \\
\hline $18^{1}$ & 23.28 & $1.84(\mathrm{~d})$ & & & \\
\hline 19 & 172.63 & & & & \\
\hline 20 & 93.72 & $8.60(\mathrm{~s})$ & & $\mathrm{C}-2$ & \\
\hline
\end{tabular}


<smiles>CCC(CC[C@H](C)C1CCC2C3CC=C4CC(O)CCC4(C)C3CCC21C)C(C)C</smiles>

$\beta$-Sitosterol (1)<smiles>CCC(/C=C/[C@H](C)C1CCC2C3CC=C4CC(O)CCC4(C)C3CCC21C)C(C)C</smiles>

Stigmasterol (2)<smiles>O=C(O)c1ccccc1O</smiles>

$o$-Hydroxy-benzoic Acid (4)<smiles>COc1cc(C(=O)O)ccc1O</smiles>

$m$-Methoxy-p-hydroxy-benzoic Acid (5)

Figure 1. Chemical structure of the substances 1, 2, 4 and 5.

\section{RESULTS AND DISCUSSION}

Structural characterization of the substances 1, 4 and 5
The spectral data together with comparison with literature data permitted to identify the substance $\mathbf{1}$ as a mixture of the steroids $\beta$-sitosterol (1) and stigmasterol (2) (Kojima et al., 1990), the substance 4 as the $o$-hydroxy-benzoic acid, and the substance $\mathbf{5}$ as the $m$-methoxy- $p$-hydroxy-benzoic acid (Figure 1 ). The ${ }^{1} \mathrm{H}$ and ${ }^{13} \mathrm{C}$ NMR $\left(\delta, \mathrm{CDCl}_{3}, 200\right.$ and $\left.50 \mathrm{MHz}\right)$ spectral data of $\mathbf{4}$ and $\mathbf{5}$ are listed below.

$o$-Hydroxy-benzoic Acid (4). ${ }^{1} \mathrm{H}$ NMR (200 $\left.\mathrm{MHz}, \mathrm{CDCl}_{3}\right) \delta_{\mathrm{H}}(\mathrm{H}$; mult.; $J$ in Hz.): 6.98 (H-3; ld; 7.95), 7.49 (H-4; td; 7.95 and 1.50), 6.90 (H-5; lt; 7.90), 7.90 (H-6; dd; 7.90 and 1.50). ${ }^{13} \mathrm{C}$ NMR (50 MHz, $\mathrm{CDCl}_{3}$ ) $\delta_{\mathrm{C}}: 111.14(\mathrm{C}-1), 162.14(\mathrm{C}-2), 117.73$ (C-3), 136.75 (C-4), 119.49 (C-5), 130.85 (C-6), 174.29 (COOH). All the values are according to literature data (Silva et al., 2006b).

$m$-Methoxy- $p$-hydroxy-benzoic Acid (5). ${ }^{1} \mathrm{H}$ NMR (200 MHz, $\left.\mathrm{CDCl}_{3}\right) \delta_{\mathrm{H}}(\mathrm{H}$; mult; $J$ in $\mathrm{Hz}): 7.57$ (H-2; d; 1.60), 6.95 (H-5; d; 8.50), 7.72 (H-6; dd; 8.50 and 1.60), $3.94\left(\mathrm{OCH}_{3} ; \mathrm{s}\right) .{ }^{13} \mathrm{C} \mathrm{NMR}\left(50 \mathrm{MHz}, \mathrm{CDCl}_{3}\right)$ $\delta_{\mathrm{C}}: 121.180(\mathrm{C}-1), 112.04(\mathrm{C}-2), 146.16(\mathrm{C}-3), 150.76$ (C-4), 114.18 (C-5), 125.16 (C-6), 171.05 (C-7), 56.10 $\left(\mathrm{OCH}_{3}\right)$. All the values are according to literature data (Costa et al., 2007).

\section{Structural characterization of 3}

The ${ }^{1} \mathrm{H}$ NMR spectrum revealed absorptions referable to three olefinic methyl groups at $\delta_{\mathrm{H}} 3.19, \delta_{\mathrm{H}}$ 3.39 and $\delta 3.69$, a vinyl group at $\delta_{\mathrm{H}} 7.95(\mathrm{dd}, J 17.85$ $\mathrm{Hz}$ and $11.48 \mathrm{~Hz}), \delta_{\mathrm{H}} 6.27(\mathrm{~d}, J 17.95 \mathrm{~Hz}), \delta_{\mathrm{H}} 6.18(\mathrm{~d}$, $J 11.10 \mathrm{~Hz}$ ) and three olefinic hydrogens at $\delta_{\mathrm{H}} 9.35, \delta_{\mathrm{H}}$ 9.51 and $\delta_{\mathrm{H}} 8.60$ which are related to the absorptions of the hydrogens 5, 10 and 20 of the porphyrin skeleton of phaeophytins (Matsuo et al., 1996; Duan et al., 2002; Silva et al., 2006b). An ethyl group was found to occur at $\mathrm{C}-8$ according to the absorptions at $\mathrm{H}-8^{2} 3.63(\mathrm{~m})$ and $\mathrm{H}-8^{1} 1.66(\mathrm{~m})$. The methoxyl hydrogens were observed as a singlet at $\delta_{\mathrm{H}} 3.91$.

Similarly, as with phaeophytin A, a five membered carbocyclic ring was present at position 13 . A keto group was found in $\mathrm{C}-13^{1}$, as indicated by the quartenary carbon resonance at $\delta_{\mathrm{C}} 189.81$. The $\mathrm{H}-13^{2}$ resonance occurred at $\delta_{\mathrm{H}} 6.30(\mathrm{~s})$ as with phaeophytin at and a methyl ester was also present at $\mathrm{C}-13^{3}$. This was indicated by $\mathrm{C}-13^{3}$ occurring as a quaternary carbon resonance at $\delta_{\mathrm{H}} 169.77$ and the $\mathrm{C}-13^{4}$ methyl carbon resonance being present at $\delta_{\mathrm{C}}$ 53.07. Nevertheless, the chemical shift revealed by the ${ }^{13} \mathrm{C}$ NMR spectrum to the carbonyl carbon at the position $13^{3}$ is not in agreement with the literature data. Matsuo et al. (1996) and Schwikkard et al. (1998) report that this value is of $\delta_{\mathrm{C}}$ 173.0. Our attribution is unambiguous since the heteronuclear correlation spectrum (HMBC) showed a three-bond correlation $\left({ }^{3} J_{\mathrm{CH}}\right)$ between the carbon $13^{3}$ $\left(\delta_{\mathrm{C}} 169.77\right)$ and the hydrogen $13^{4}\left(\delta_{\mathrm{H}} 3.91\right)$, and a twobond correlation $\left({ }^{2} J_{\mathrm{CH}}\right)$ between the carbon $13^{3}$ and the 


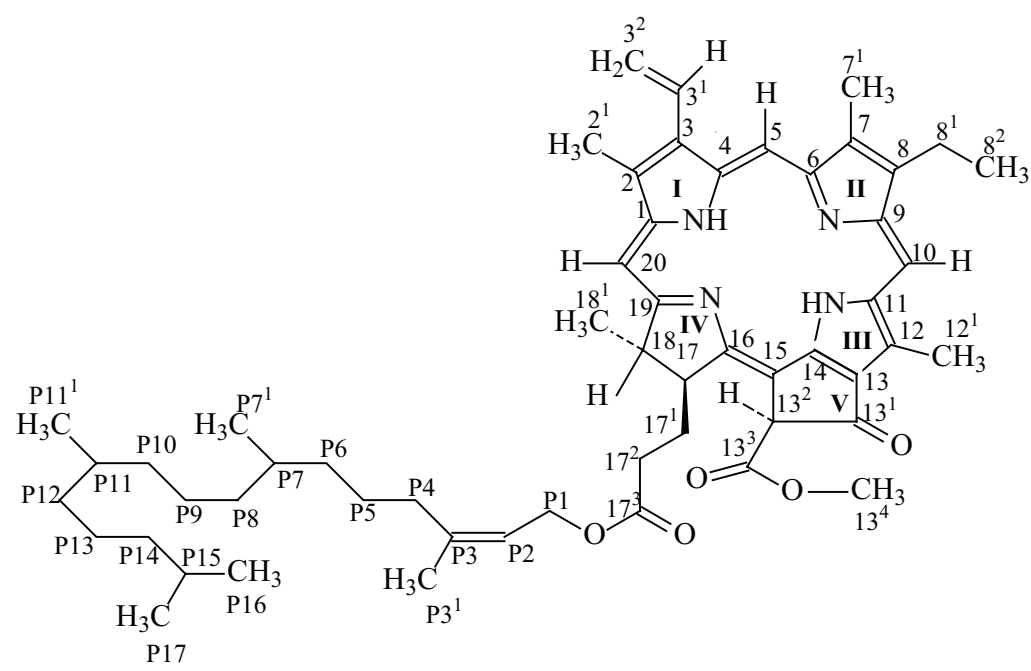

Figure 2. Chemical structure of $\mathbf{3}$ (phaeophytin A)

hydrogen $13^{2}\left(\delta_{H} 6.30\right)$, thus strengthening our data.

Phaeophytin A is substituted with a phytyl ester at $\mathrm{C}-17^{3}$ (Schwikkard et al., 1998). The presence of an envelope of signals in the aliphatic region of the ${ }^{1} \mathrm{H}$ NMR spectrum of 3 and the resonance found to $\mathrm{C}-17^{3}$ $\left(\delta_{\mathrm{C}} 173.18\right)$ suggests the presence of a phytyl ester in the molecule when compared with the data of the $17^{3}$-ethoxy-pheophorbide A (Silva et al., 2006b) which does not have the phytyl.

The COSY spectrum confirmed the presence of vinyl and ethyl groups showing coupling between $\delta_{\mathrm{H}} 7.95\left(\mathrm{H}-3^{1}\right)$ and $\delta_{\mathrm{H}} 6.27\left(\mathrm{H}-3^{2}\right)(E), \delta_{\mathrm{H}} 6.18\left(\mathrm{H}-3^{2}\right)$ $(Z)$, referable to vinyl hydrogens, and between $\delta_{\mathrm{H}} 3.63$ $\left(\mathrm{H}-8^{1}\right)$ and $\delta_{\mathrm{H}} 1.66\left(\mathrm{H}-8^{2}\right)$ the ethyl hydrogens.

The other assignments of carbons and hydrogens were determined based on all spectral data (Table 1) and on comparison with literature data (Matsuo et al., 1996; Schwikkard et al., 1998; Duan et al., 2002; Silva et al., 2006b), permitting to identify the substance 3 as being phaeophytin A (Figure 2), substance described for the first time in the genus Richardia.

\section{ACKNOWLEDGMENTS}

The authors wish to express their thanks to CAPES and CNPp and IMSEAR for financial support and to CENAUREM for providing the spectra of phaeophytin A.

\section{REFERENCES}

Adekunle AA 2000. Antifungal property of the crude extracts of Brachystegia eurycoma and Richardia brasiliensis. Nig J Nat Prod Medicine 4: 70-72.

Agra MF, Freitas PF, Barbosa-Filho JM 2007 Synopsis of the plants known as medicinal and poisonous in Northeast Brazil. Rev Bras Farmacogn 17: 114-140. Albuquerque UP, Hanazaki N 2006. As pesquisas etnodirigidas na descoberta de novos fármacos de interesse médico e farmacêutico: fragilidades e pespectivas. Rev Bras Farmacogn 16(Supl.): 678-689.

Almeida RN, Navarro DS, Barbosa-Filho JM 2001. Plants with central analgesic activity. Phytomedicine 8 : 310-322.

Amaral FMM, Ribeiro MNS, Barbosa-Filho JM, Reis AS, Nascimento FRF, Macedo RO 2006. Plants and chemical constituents with giardicidal activity. Rev Bras Farmacogn 16(Supl.): 696-720.

Barbosa-Filho JM, Vasconcelos THC, Alencar AA, Batista LM, Oliveira RAG, Guedes DN, Falcão HS, Moura MD, Diniz MFFM, Modesto-Filho J 2005. Plants and their active constituents from South, Central, and North America with hypoglycemic activity. Rev Bras Farmacogn 15: 392-413.

Barbosa-Filho JM, Piuvezam MR, Moura MD, Silva MS, Lima KVB, Cunha EVL, Fechine IM, Takemura OS 2006a. Anti-inflammatory activity of alkaloids: A twenty-century review. Rev Bras Farmacogn 16: 109-139.

Barbosa-Filho JM, Medeiros KCP, Diniz MFFM, Batista LM, Athayde-Filho PF, Silva MS, Cunha EVL, Almeida JRGS, Quintans-Júnior LJ 2006b. Natural products inhibitors of the enzyme acetylcholinesterase. Rev Bras Farmacogn 16: 258-285.

Barbosa-Filho JM, Martins VKM, Rabelo LA, Moura MD, Silva MS, Cunha EVL, Souza MFV, Almeida RN, Medeiros IA 2006c. Natural products inhibitors of the angiotensin converting enzyme (ACE). A review between 1980-2000. Rev Bras Farmacogn 16: 421-446.

Barbosa-Filho JM, Nascimento-Júnior FA, Tomaz ACA, Athayde-Filho PF, Silva MS, Cunha EVL, Souza MFV, Batista LM, Diniz MFFM 2007. Natural products with antileprotic activity. Rev Bras Farmacogn 17: 141-148.

Brandão MGL, Cosenza GP, Moreira RA, Monte-Mor RLM 2006. Medicinal plants and other botanical products from the Brazilian Official Pharmacopoeia. Rev Bras Farmacogn 16: 408-420. 
Carlini EA, Rodrigues E, Mendes FR, Tabach R, Gianfratti B 2006. Treatment of drug dependence with Brazilian herbal medicines. Rev Bras Farmacogn 16: 690-695.

Carvalho MG, Alves JS, Cunha EVL, Barbosa-Filho JM, Silva MS 2006. Pimarane diterpenes and sesquiterpene from Salzmmania nitida. An Acad Bras Cienc 78: 17-22.

Coelho VPM, Agra MF, Barbosa MRV 2006. Estudo farmacobotânico das folhas de Tocoyena formosa (Cham. \& Schltdl.) K.Schum. (Rubiaceae). Rev Bras Farmacogn 16: 170-177.

Costa DA, Silva DA, Cavalcanti AC, Medeiros MAA, Lima JT, Cavalcante JMS, Silva BA, Agra MF, Souza MFV 2007. Chemical constituents from Bakeridesia pickelii Monteiro (Malvaceae) and the relaxant activity of kaempferol-3-O- $\beta$-D-(6"-E- $p$-coumaroyl) glucopyranoside on guinea-pig ileum. Quim Nova 30: 901-903.

Duan H, Takaishi Y, Momota H, Ohmoto Y, Taki T 2002. Immunosuppresive constituents from Saussurea medusa. Phytochemistry 59: 85-90.

Edeoga HO, Okwu DE, Mbaebie BO 2005. Phytochemical constituents of some Nigerian medicinal plants. Afr J Biotechnol 4: 685-688.

Falcão HS, Lima IO, Santos VL, Dantas HF, Diniz MFFM, Barbosa-Filho JM, Batista LM 2005. Review of the plants with anti-inflammatory activity studied in Brazil. Rev Bras Farmacogn 15: 381-391.

Funari CS, Ferro VO 2005. Uso ético da biodiversidade brasileira: necessidade e oportunidade. Rev Bras Farmacogn 15: 178-182.

Hauser EW, Parham SA 1969. Effects of annual weeds and cultivation on the yield of peanuts. Weed Res 9: 192-197.

Kojima H, Sato N, Hatano A, Ogura H 1990. Sterol glucosides from Prunella vulgaris. Phytochemistry 29: 2351-2355.

Leitão SG, Castro O, Fonseca EM, Julião LS, Tavares ES, Leo RRT, Vieira RC, Oliveira DR, Leitão GG, Martino V, Sulsen V, Barbosa YAG, Pinheiro DPG, Silva PEA, Teixeira DF, Lourenço MCS 2006. Screening of Central and South American plant extracts for antimycobacterial activity by the Alamar Blue test. Rev Bras Farmacogn 16: 6-11.

Lewis WH, Oliver RL 1974. Revision of Richardia (Rubiaceae). Brittonia 26: 271-301.

Lima MRF, Ximenes CPA, Luna JS, Sant'Ana AEG 2006. The antibiotic activity of some Brazilian medicinal plants. Rev Bras Farmacogn 16: 300-306.

Matsuo A, Ono K, Hamasaki K, Nozaki H 1996. Phaeophytins from a cell suspension culture of the liverwort Plagiochila ovalifolia. Phytochemistry 42: 427-430.

Mongrand S, Badoc A, Patouille B, Lacomblez C, Chavent M, Bessoule J 2005. Chemotaxonomy of the Rubiaceae family based on leaf fatty acid composition. Phytochemistry 66: 549-559.

Monquero PA 2003. Dinâmica populacional e mecanismos de tolerância de espécies de plantas daninhas ao herbicida glyphosate. Tese (doutorado) - Escola Superior de Agricultura Luiz de Queiroz, Piracicaba, $99 \mathrm{p}$.
Monquero PA, Christoffoleti PJ 2003. Dinâmica do banco de sementes em áreas com aplicação freqüente do herbicida glyphosate. Planta Daninha 21: 63-69.

Monquero PA 2005. Plantas transgênicas resistentes aos herbicidas: situação e perspectivas. Bragantia 64: 517-531.

Monquero PA, Cury JC, Christoffoleti PJ 2005. Controle pelo glyphosate e caracterização geral da superfície foliar de Commelina benghalensis, Ipomoea hederifolia, Richardia brasiliensis e Galinsoga parviflora. Planta Daninha 23: 123-132.

Oliveira FQ, Gobira B, Guimarães C, Batista J, Barreto M, Souza M 2007. Espécies vegetais indicadas na odontologia. Rev Bras Farmacogn 17: 466-476.

Pedrinho Júnior AFF, Bianco S, Pitelli RA 2004. Acúmulo de massa seca e macronutrientes por plantas de Glycine max e Richardia brasiliensis. Planta Daninha 22: 53-61.

Robbrecht E 1988. Tropical woody Rubiaceae. Opera Botanica Belgica 1: 1-271.

Rocha LG, Almeida JRGS, Macedo RO, Barbosa-Filho JM 2005. A review of natural products with antileishmanial activity. Phytomedicine 12: 514-535.

Rocha FD, Pereira RC, Kaplan MAC, Teixeira VL 2007. Produtos naturais de algas marinhas e seu potencial antioxidante. Rev Bras Farmacogn 17: 631-639.

Ronchi CP, Terra AA, Silva AA, Ferreira LR 2003. Acúmulo de nutrientes pelo cafeeiro sob interferência de plantas daninhas. Planta Daninha 21: 219-227.

Saúde-Guimarães DA, Faria AR 2007. Substâncias da natureza com atividade anti-Trypanosoma cruzi. Rev Bras Farmacogn 17: 455-465.

San Martin Matheis HA 2004. Efeitos de diferentes coberturas mortas obtidas a partir do manejo mecânico com roçadeira lateral na dinâmica populacional de plantas daninhas em citros. Dissertação (mestrado) - Escola Superior de Agricultura Luiz de Queiroz, Piracicaba, $68 \mathrm{p}$.

Schwikkard SL, Mulholland DA, Hutchings A 1998. Phaeophytins from Tapura fisheri. Phytochemistry 49: 2391-2394.

Silva JS, Moura MD, Oliveira RAG, Diniz MFFM, BarbosaFilho JM 2003. Natural products inhibitors of ovarian neoplasia. Phytomedicine 10: 221-232.

Silva MIG, Gondim APS, Nunes IFS, Sousa FCF 2006 a. Utilização de fitoterápicos nas unidades básicas de atenção à saúde da família no município de Maracanaú (CE). Rev Bras Farmacogn 16: 455-462.

Silva DA, Silva TMS, Lins ACS, Costa DA, Cavalcante JMS, Matias WN, Souza MFV 2006b. Constituintes químico e atividade antioxidante de Sida galheirensis Ulbr. (Malvaceae). Quim Nova 29: 1250-1254.

Souza LA, Mourão KSM, Moscheta IS, Rosa SM 2003. Morfologia e anatomia da flor de Pilocarpus pennatifolius Lem. (Rutaceae). Rev Bras Bot 26: 175-184.

Vilegas W, Cardoso CAL 2007. Controle químico de qualidade de fitoterápicos e plantas medicinais. In: Yunes RA, Cechinel Filho V. Química de produtos naturais, novos fármacos e a moderna farmacognosia. $1 \mathrm{ed}$ Itajaí: Ed. Univali, 303 p. 